\section{Case Reports in Gastroenterology}

Case Rep Gastroenterol 2017;11:593-598

DOI: $10.1159 / 000481162$

Publisned online: Uctober 6, 2017
The Author(s)

Published by S. Karger AG, Basel www.karger.com/crg

This article is licensed under the Creative Commons Attribution-NonCommercial 4.0 International License (CC BY-NC) (http://www.karger.com/Services/OpenAccessLicense) Usage and distribution for commercial purposes requires written permission.

\title{
A Tale of Two Lymphomas
}

\author{
Vikrant Parihar ${ }^{a}$ Paul Crotty ${ }^{b}$ Deidre McNamara ${ }^{a, c, d}$ \\ ${ }^{a}$ Department of Gastroenterology, AMNCH, Dublin, Ireland; ${ }^{b}$ Department of Pathology, \\ AMNCH, Dublin, Ireland; ${ }^{\circ}$ Trinity College Dublin, Dublin, Ireland; ${ }^{d}$ TAGG (Trinity Academic \\ Gastroenterology Group), Dublin, Ireland
}

\section{Keywords}

Refractory coeliac disease · Lymphoma · Massive gastrointestinal bleeding

\section{Abstract}

We present a patient with coeliac disease who developed refractory coeliac disease II, which was complicated by the development of metachronous lymphomas.

$$
\begin{aligned}
& \text { C } 2017 \text { The Author(s) } \\
& \text { Published by S. Karger AG, Basel }
\end{aligned}
$$

\section{Introduction}

Refractory coeliac disease (RCD) is a rare disease of the gastrointestinal tract characterised by crampy abdominal pain, diarrhoea, gastrointestinal bleeding, and weight loss in patients with coeliac disease (CD) and is associated with loss of response to standard therapy which is gluten-free diet (GFD). It occurs as type I and II, with type II having a poor outcome due to the development of complications. We present a patient with CD who went on to develop RCDII despite strict adherence to a GFD. The case was complicated by the development of metachronous lymphomas and massive gastrointestinal bleeding. This case emphasises 


\section{Case Reports in \\ Gastroenterology}

Case Rep Gastroenterol 2017;11:593-598

DOI: 10.1159/000481162

(c) 2017 The Author(s). Published by S. Karger AG, Base www.karger.com/crg

Parihar et al.: A Tale of Two Lymphomas

the challenges in the diagnosis of RCD and the need for increased awareness of this entity. This will improve early recognition with possibly better outcomes.

\section{Case Report}

A 69-year-old male presented with a 3-month history of weight loss, watery non-bloody diarrhoea, low energy, and pain in the left hip radiating to the leg. His history consisted of stroke with no residual deficit 6 years ago and non-deforming rheumatoid arthritis. He was on aspirin and sulfasalazine. He was a smoker of 20 pack-years having stopped 7 years ago. He consumed alcohol socially.

Systemic examination was normal. He had recently been diagnosed with CD and commenced a GFD. MRI followed by a PET scan showed a mass at the fourth lumbar vertebra with no disease elsewhere, and the subsequent biopsy revealed a diagnosis of T-cell lymphoma with anaplastic large cell morphology, CD30 positive and ALK-1 negative. The patient was treated with CHOP (cyclophosphamide, doxorubicin, vincristine, and prednisone) $\times 8$ cycles and radiotherapy $40 \mathrm{~Gy} / 20$ fractions. A follow-up PET scan 6 months after completion of therapy suggested a residual soft tissue mass in the left posterior element of L4 with minimal FDG accumulation (residual disease). However, a repeat L4 biopsy showed therapyrelated changes only, with no evidence of lymphoma. The patient was admitted again 24 months later with diarrhoea and 2-stone weight loss. He looked cachectic with generalised oedema, but on examination, there was no lymphadenopathy or organomegaly. His laboratory work-up revealed a normocytic anaemia, hypoalbuminaemia with normal anti-transglutaminase antibody titre (Table 1). Given significant risk of enteropathy-associated T-cell lymphoma (EATL), investigations to exclude this diagnosis were performed. Scans including whole-body CT and PET showed no evidence of recurrence of his anaplastic large cell lymphoma, but an MRI of the small bowel showed mildly thickened loops of the jejunum in the central abdomen and right flank without dilatation. Oesophagogastroduodenoscopy revealed severely active CD (Fig. 1), and colonoscopy was macroscopically normal with normal colonic and terminal ileal biopsies. Biopsy results from the second part of the duodenum showed total villus atrophy with intraepithelial lymphocytes that were within normal limits. Subsequent immunostaining confirmed a normal number of aberrant intraepithelial T lymphocytes (IELs) (Fig. 2). A diagnosis of RCDII was made, and the patient was treated with total parenteral nutrition, blood products (red cell concentrate, platelet, fibrinogen, albumin), parenteral steroids followed by "naked" unencapsulated budesonide. He was later treated with oral cladribine, a synthetic purine nucleoside homologue with cytotoxic activity, but was not considered a candidate for autologous stem cell transplant given his age and poor performance status. He did not respond to cladribine, and developed a catastrophic upper gastrointestinal bleed 4 weeks after admission which could not be controlled endoscopically. A mesenteric angiogram with embolisation of jejunal branches was performed, and haemostasis was achieved (Fig. 3). Unfortunately, he went on to develop severe systemic sepsis with multiple organ dysfunction after the procedure. Given the poor prognosis, treatment was not escalated, and he died 3 days later. A limited post-mortem examination (requested by next of kin) showed axillary lymph node T-cell lymphoma likely related to the CD. 


\section{Discussion}

CD is a T-cell mediated reversible enteropathy induced by ingestion of gluten with a significant intestinal injury. CD is associated with a doubling of non-Hodgkin lymphoma (NHL) risk, with an OR of 2.1. The OR for diffuse large B-cell lymphoma is 2.8 in contrast to an OR of 17 for T-cell lymphoma [1].

RCD is a subset of the disease, which is characterised by a continuous gluten independent immune response that does not respond to standard treatment with a GFD [2]. RFD is typically divided into 2 subgroups - RCDI and RCDII, differentiated by the presence or absence of abnormal IELs on mucosal biopsy [3]. In RCDI, the IEL phenotype is normal, whereas the abnormal phenotype in RCDII is supported by the loss of normal surface markers CD3, CD4, and CD8 with preserved expression of intracytoplasmic CD3.

Progress to EATL occurs in $60-80 \%$ of RCDII sufferers within 5 years [4]. Survival rates for patients with EATL are low, at 11-20\% at 5 years [4]. However, non-intestinal B-cell and T-cell NHL together constitute the majority of CD-associated malignant lymphomas [5]. "Naked" budesonide, as used in this case, assists with the enteric delivery of an active steroid, rather than standard steroid formulations and can be utilised initially to manage the disease. Autologous stem cell treatment is now the standard of care in patients with RCDII to prevent progression [6]. Mesenchymal stem cell infusions and calamine (anti-IL-15) are newer experimental modalities being tried [7]. On the other hand, RCDI is managed with immunosuppressive therapy, such as prednisolone/budesonide in combination with azathioprine.

Our case is unusual in the development of metachronous lymphomas at 2 different locations. He initially appears to have had a responsive disease when he had a non-intestinal Tcell lymphoma, not typical EATL, and only in the terminal phase did he have evidence of refractory coeliac/ulcerative jejunitis with additional post-mortem diagnosis of axillary lymph node T-cell lymphoma. However, there is always a possibility that given the multifocal nature of the condition, his RCD might have been missed at the index gastroscopy. So, in summary, the unique features and teaching points of this case are the occurrences of 2 different metachronous lymphomas in 1 patient. We need to be cognizant of the need to look for RCDII if patients with the coeliac disease develop non-GI lymphoma disease. Also, RCDII has significant morbidity in its own right due to bleeding and malabsorption; so, early referral for autologous stem cell transplant is mandatory. However, due to the rarity of the disorder, further large-scale studies are needed, and multi-centre cooperation will be essential to achieve meaningful results.

\section{Statement of Ethics}

The authors have no ethical conflicts to disclose.

\section{Disclosure Statement}

No financial disclosures for any of the authors. 


\section{Case Reports in \\ Gastroenterology}

\begin{tabular}{l|l}
\hline Case Rep Gastroenterol 2017;11:593-598 \\
\hline DOI: 10.1159/000481162 & $\begin{array}{l}\text { C } 2017 \text { The Author(s). Published by S. Karger AG, Basel } \\
\text { www.karger.com/crg }\end{array}$ \\
\hline
\end{tabular}

Parihar et al.: A Tale of Two Lymphomas

\section{References}

1 Smedby KE, Åkerman M, Hildebrand H, Glimelius B, Ekbom A, Askling J: Malignant lymphomas in coeliac disease: evidence of increased risks for lymphoma types other than enteropathy-type $\mathrm{T}$ cell lymphoma. Gut 2005;54:54-59.

2 Dewar DH, Donnelly SC, McLaughlin SD, Johnson MW, Ellis HJ, Ciclitira PJ: Celiac disease: management of persistent symptoms in patients on a gluten-free diet. World J Gastroenterol 2012;18:1348-1356.

3 Rubio-Tapia A, Murray J: Recent advances in clinical practice: classification and management of refractory coeliac disease. Gut 2010;59:547-557.

-4 Al-Toma A, Verbeek WH, Hadithi M, von Blomberg BM, Mulder CJ: Survival in refractory coeliac disease and enteropathy-associated T-cell lymphoma: retrospective evaluation of single-centre experience. Gut 2007;56:1373-1378.

5 Halfdanarson TR, Litzow MR, Murray JA: Hematologic manifestations of celiac disease. Blood 2007;109:412-421.

-6 Tack GJ, Wondergem MJ, Al-Toma A, Verbeek WH, Schmittel A, Machado MV, Perri F, Ossenkoppele GJ, Huijgens PC, Schreurs MW, Mulder CJ: Auto-SCT in refractory celiac disease type II patients unresponsive to cladribine therapy. Bone Marrow Transplant 2011;46:840-846.

7 Meresse B, Korneychuk N, Malamut G, Cerf-Bensussan N: Interleukin-15, a master piece in the immunological jigsaw of celiac disease. Dig Dis 2015;33:122-130.

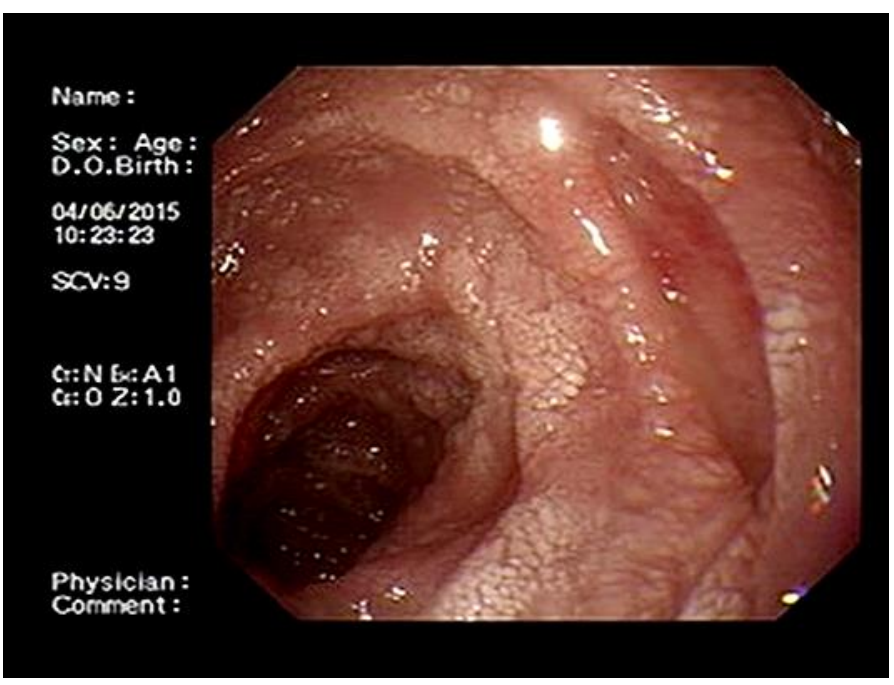

Fig. 1. Endoscopic duodenal appearance. 

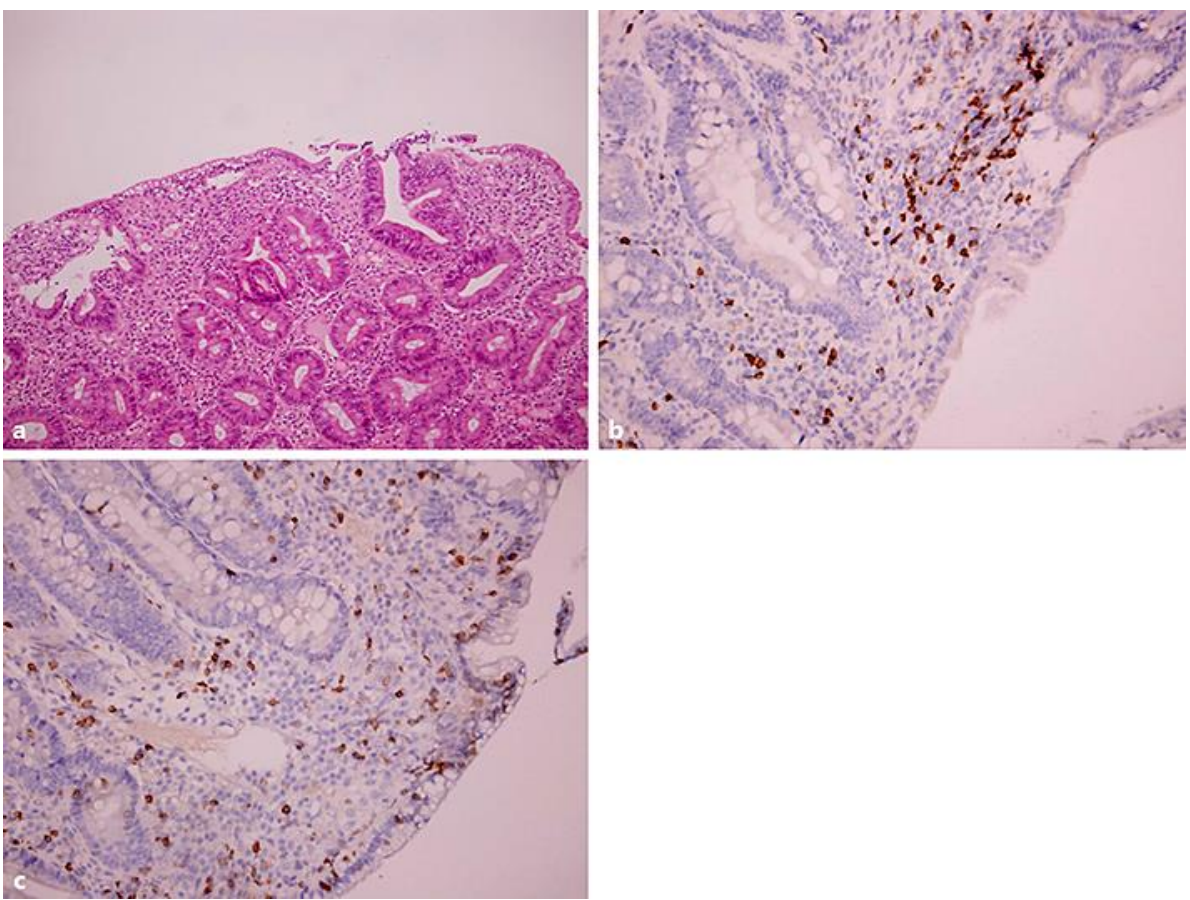

Fig. 2. a Duodenal biopsy with villous atrophy. $\times 100$. b Immunostaining with retention of CD3. $\times 100$. c Immunostaining with loss of CD8. $\times 100$.
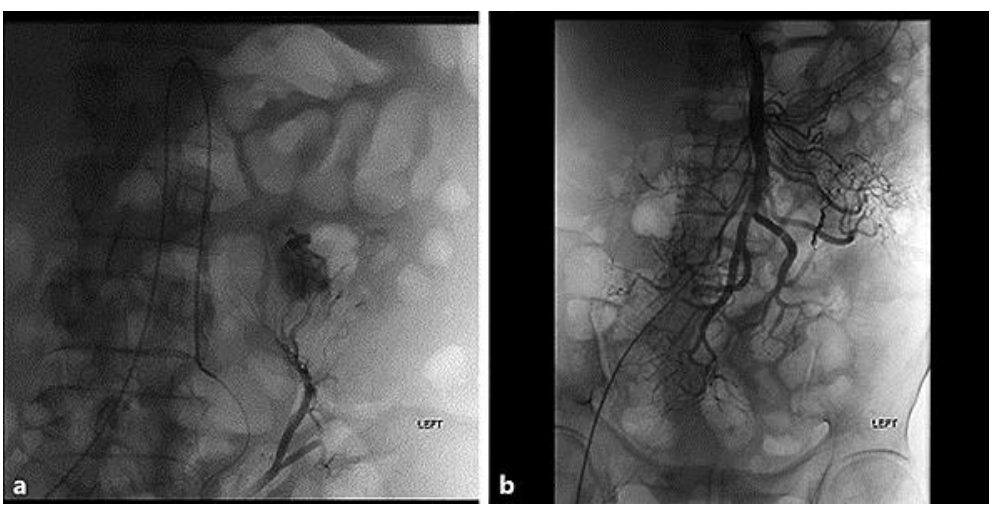

Fig. 3. a Mesenteric angiogram demonstrating bleeding from jejunal branches. b Coiling of bleeding branches. 


\section{Case Reports in Gastroenterology}

Table 1. Laboratory values

Hb
MCV
White cell count
Platelet count
LFTs and U and E
Albumin
Stool C+S
TTG
LDH
Vit D

$9.6(13.0-17.5)$

$80 \mathrm{fL}(79.0-96.0)$

$8 \times 10^{9} / \mathrm{L}(4.0-11.0)$

$350 \times 10^{9} / \mathrm{L}(140-400)$

normal

19 (35-45)

negative

4.1 and $3.5(0.0-3.9 \mathrm{U} / \mathrm{mL})$

$159(<250)$

$12(>50)$ 